IRSH 47 (2002), pp. I 59-I75 DOI: I0.1017/S0020859002000822

(C) 2002 Internationaal Instituut voor Sociale Geschiedenis

\title{
On "De-industrialization" and the Crisis of Male Identities
}

\author{
Chitra Joshi
}

The last two decades in India have seen the decline of traditional factory industries and a growing process of informalization and casualization of labour. The crisis of industries like textiles and steel has meant a virtual decimation of a working class in old industrial centres. This paper will look at the phenomenon of de-industrialization and its implications for a labouring population whose lives were intimately connected with industrial work.

De-industrialization at the end of twentieth century and the beginning of the twenty-first refers to a process quite different from de-industrialization in the nineteenth century. Nationalist accounts of a linear decline of Indian handicrafts under the onslaught of imported manufactures have long been questioned. Critics of nationalist frames have focused on the lack of statistical evidence showing a decline, ${ }^{\mathrm{I}}$ and critiqued the theoretical assumptions of the de-industrialization argument. Big industries, recent studies point out, have not always displaced the small: small-scale industries continued to survive and expand through a process of adaptation and innovation, and became in fact an integral feature of industrialization in India. ${ }^{2}$ Despite differences, the protagonists of the debate have shared a common focus on the decline of small-scale industry. Today deindustrialization refers to another kind of process - one in which labour

I. For a discussion of de-industrialization within a nationalist paradigm, see B. Chandra, Rise and Growth of Economic Nationalism in India (New Delhi, I966), chs 2 and 3; A.K. Bagchi, "Deindustrialization in India in the Nineteenth Century: Some Theoretical Implications", Journal of Development Studies, I 2 (1976), pp. I 35-I64. For critiques questioning the statistical basis of de-industrialization, see Daniel and Alice Thorner, Land and Labour in India (New Delhi, I962), ch. 6; J. Krishnamurthy, "Changes in the Composition of the Workforce in Manufacturing, I90I-I95 I: A Theoretical and Empirical Analysis", Indian Economic and Social History Review, 4 (1967), pp. I-I6.

2. For a critique on these lines, see Tirthankar Roy, Artisans and Industrialization: Indian Weaving in the Twentieth Century (Delhi, I993); Konrad Specker, "Madras Handlooms in the Nineteenth Century", in Tirthankar Roy (ed.), Cloth and Commerce: Textiles in Colonial India (New Delhi, 1996), pp. 175-217. 
in large factories is being displaced by casual and informal labour. A large network of informal labour, however, is not a new feature. It has always formed a part of the labour market in centres of large-scale industry like Bombay, Calcutta, Ahmedabad, and Kanpur. In cities like Kanpur, where the informal was closely tied to the formal, a decline in the latter has created a crisis for the informal economy.

What happens to urban lives in this context? What are the work and household strategies by which workers confront this situation? How do working-class men out of work perceive themselves and their lives? In trying to understand what processes of displacement and marginalization mean to working-class men, I begin by looking at the political culture of a city in north India, Kanpur, a major industrial centre. ${ }^{3}$

Kanpur, which was a trading centre connected with the East India Company trade since the late eighteenth century, became an important centre of the textile and leather industry in north India in the nineteenth century. Like Ahmedabad in western India, the city drew its labour supply largely from the surrounding countryside. In periods of famine and agrarian distress the influx into the city was much greater. The First and Second World Wars were major phases of expansion, with the Kanpur factories taking bulk orders for the British armies. Till the i96os, textile and leather factories, and other small units in Kanpur employed over 80,000 workers. Apart from these, a host of small cottage units producing nuts, bolts, bearings, leather goods, furniture, and packing cases supplied materials to the large factories. Thousands were employed as daily labourers, loading and unloading goods coming into and going out of the city. Business for tea stalls, tobacco and betel nut shops, grocery, and other cloth shops outside the factory compounds was intimately connected with workers' pay day. Around shift times on pay day hundreds of workers milled around. Business was brisk. ${ }^{4}$

Today, smokeless mill chimneys, towering brick structures, and deserted mill compounds stand as silent reminders of the past of the city. Most textile mills are closed. Among the units managed by the nationalized British India Corporation, only the woollen mills run, but at less than a quarter of their former strength. Two other textile mills, Muir and New Victoria, which were controlled by the state-run National Textile Corporation, stopped production almost ten years ago, but they have a small number of workers on their payrolls. The daily routine for these workers consists of reporting for attendance at shift times, in the morning or afternoon. A large number of permanent employees of the

3. In looking at working-class worlds this essay draws heavily on two sets of oral narratives: (I) stories of individual lives collected between the late I970s and early I980s; and (2) narratives from more than Ioo working-class households collected between between 1997 and 2002.

4. For more on Kanpur see C. Joshi, Lost Worlds (New Delhi, 2002), ch. I. 


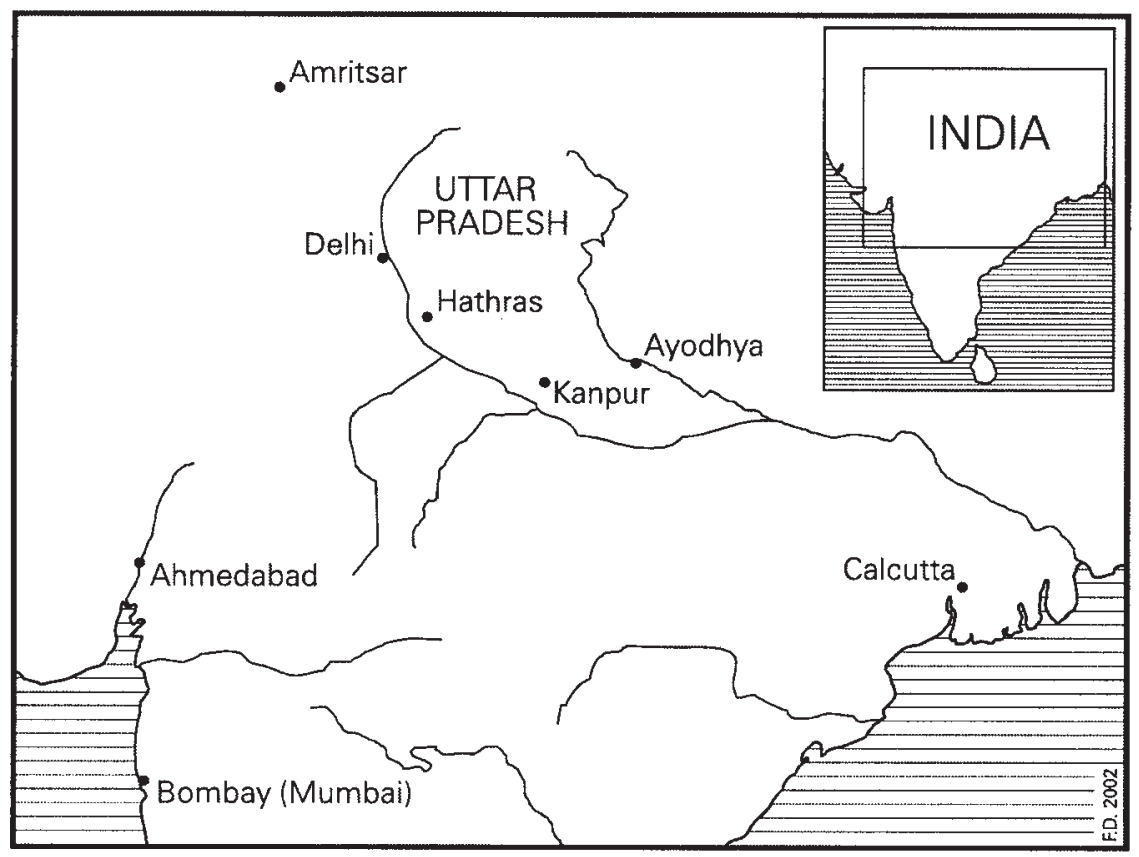

Figure I. North India

closed units have left under voluntary retirement schemes (VRS). Outside the factory gates, teashops wear a deserted look, stalls have their shutters down, and no vendors line the roads, no people mill around. Earlier, petty vending was a recourse open to workers during spells of unemployment. Today, there are no clients for vendors, no noise and bustle at the Sunday markets in working-class neighbourhoods. Yet the flow of migrants to the city continues, adding to the scores of rickshaw pullers, vendors, casual labourers, and the unemployed. Old centres of industry like Kanpur remain predominantly working-class cities but with a labouring population that is increasingly invisible. The workforce is hidden in homes, in alleys and bye-lanes, working some days in the week, waiting other days, sometimes weeks on end. In a context when jobs for men in the "formal" sector are shrinking, women - never very visible in the factory labour force - form an important part of the invisible workforce in the city. Women sew, make brushes, and uppers for leather sandals, cut rubber straps for slippers, roll bidis, wrap toffees, and do a host of other smallwaged jobs at home and in small workshops not enumerated as factories. ${ }^{5}$

5. It is virtually impossible to get figures of the numbers employed in these small establishments. Records are available only for registered units. And these understate the numbers employed and do not give the breakdown for men and women. 
The closure of mills in Kanpur, and in other centres of large-scale industry in India, means more than an economic loss to workers - it has also meant the death of a political culture in industrial cities. In contrast to the present, when labour is increasingly invisibilized in the public sphere, the working class stamped the city with its presence through the militant struggles of the I920s and I930s. Industrial labour was an important constituency to which all political parties and leaders had to reach out. The politics of labour in Kanpur in the r930s shaped the political context in the entire province. Local nationalists came into conflict with provincial leaders and eventually the strength of the local movement had a radical impact, pushing the provincial Congress into supporting working-class demands. In the eyes of colonial officials and the predominantly European entrepreneurs in the city the Congress was seen as taking a Left turn. Cartoons in contemporary newspapers capture the panic created by working-class militancy in 1937-1938.6 In popular discourse, the city came to be known as "Red City" (Lal Kanpur). A history of the labour movement in Kanpur by a worker-militant chronicles the entire story of the city in terms of heroic struggles by workers. 7 The solidarities forged through collective struggles left their imprint on the political culture of the city in the decades to follow. For old trade unionists who lived through those times, the epithet Lal Kanpur remained fixed even in bleaker times. It was almost as if it was their city - it bore a name that they gave to it.

The world of radical trade-union politics was a male world. It reaffirmed and did not contest the masculinized nature of the public sphere in the city. Mass meetings during strikes were male affairs. If women formed a part of the audience, their presence goes unrecorded in official and unofficial reports. There were moments of inversion within this gendered sphere when women strikers appeared aggressively in the forefront, picketing mill gates during the strikes in 1938 . Till the recent phase of decline of the labour movement, entry into the world of trade-union politics was valorized by young male workers. Recognition as leaders even at the factory and departmental level gave a new identity. Many workers who lived through those times remembered that as young workers they always yearned to become leaders. ${ }^{8}$ Shriram, who worked in Kanpur factories in the I930s and I940s, recalled that the most important criteria for selecting factory-level leaders was their reputation for being fearless (nidar). In speeches at mill gates and outside during strikes, trade-union leaders openly attacked and abused managers and the government. Such acts that

\footnotetext{
6. See Joshi, Lost Worlds.

7. Sudarshan Chakr, Kanpur Mazdur Andolan ka Itihaas (Kanpur, I986).

8. Interviews with workers like Shriram, Raghubir, and Moolchand who worked in the Kanpur factories in the I920s and I940s.
} 
momentarily inverted hierarchies were empowering. Shriram himself was a secretary of the Muir Mills committee. The elevation to this post, he narrates, immediately brought him into fame. He proudly declares that after his militant role during strikes his name figured along with other important local and provincial leaders in the United Provinces.

Many workers who acquired recognition as trade-union leaders were not completely anonymous earlier. Long before he became a trade-union activist, Shriram was known and feared as a neighbourhood dada. ${ }^{9}$ Tracing his early days in the city, Shriram recounted how he became a regular at a local akhara soon after he started work. ${ }^{10}$ Sport and physical culture at the akhara were important both as entertainment and as an initiation into the male world of the city. In the street culture of the city, where violent affrays between muscle men could draw an entire neighbourhood into action, dadas could act both as protectors and predators for communities. A favourite pastime in his dada days, Shriram recollected, was drinking and engaging in brawls. ${ }^{11}$ Like other local dadas, he moved around with a band of followers. Dadas like him had a style and appearance that marked them off - their fashionable clothes, their swagger, and their whole bearing was distinct.

Trade-union leaders both claimed their association with the masculinist dada world and distanced themselves from it. Typically the dada world is represented as an element of the distant past from which leaders emerged empowered, enriched by the experience of that world, but it was a past that they had to renounce. In his retrospective recounting of his life, Shriram seeks to distance himself from his dada past once he became a trade-union activist. Unlike a dada, who was distinguished by his capacity to consume, a communist militant in the I930s was recognized by his austerity and acts of renunciation. After becoming a trade-union leader, Shriram tells us, he renounced drinking and the extravagance of his dada ways and vowed to remain celibate and virtuous.

Despite the clear demarcation drawn between the world of the tradeunion activist and the dada in Shriram's narrative, his own experiences reflect the fluidity of the divisions between the two worlds in an industrial city like Kanpur. The visible hyper-masculinity of the dada world was in some ways characteristic of the culture of the city as a whole. To acquire a sense of power and control in the city as a trade-union leader or as a local dada required an aggressive masculinity. Even the minor leaders within mill departments were tough guys who could throw their weight around and bully other workers. Like local dadas who boasted about exploits

9. Dada: a tough aggressive male who could bully and threaten people in the neighbourhood. The term used for them in official and nonofficial discourse, goonda, has more pejorative connotations. Anyone categorized as a goonda was seen as a criminal.

I0. Akhara: a centre for wrestling and various other forms of physical activity.

I I. Shriram, Ek Sarvahara ka Jivan Vritanta (Kanpur, n.d.), p. I2. 
against predators in the neighbourhood, trade-union leaders bragged about avenging strikebreakers. Shriram narrated how, as a trade-union leader, his main job was to fight back against anyone daring to break a strike. $^{\mathrm{I} 2}$

Such aggressiveness was an important survival strategy for workingclass men in the city. To resist being bullied by foremen and supervisors, to find work in the daily coolie market for casual labour, to avoid being fleeced by corrupt moneylenders - all required street-smart ways. For fresh migrants, patronage by dadas in the neighbourhood was important to get a foothold in the labour market. For some, spaces like the akhara had a role to play in forging networks. Regular visitors to the akhara in the I930s and the 1940 s had their addas where they gathered. ${ }^{13}$ Boastful talks about pugilistic exploits, one-upmanship, were an essential part of such addas. Once he became associated with them, a man tried to identify with the image of an akhara pahalwan. ${ }^{14}$ Shriram soon became an object of envy for neighbourhood dadas and pahalwans. He was proud to earn the title of the dada of Colonelganj. Similarly, partridge fighting, a sport popular among some workers, was more than a source of entertainment. ${ }^{15}$ Bets were placed on birds, which had been fed and trained to fight. Sports like wrestling and partridge fighting were both expressing as well as creating a culture of masculinity - of violence and aggression.

Various spaces in the city provided a space for bonding between male workers. The streets through which hundreds of workers walked in groups or rode on bicycles were spaces which the working class marked with its presence. During periods of working-class upsurge, and during major riots the numbers on the streets swelled to thousands. Today, when the mills are shut and hardly any men can be seen outside factory gates, workers nostalgically talk about the noise and bustle outside factories at shift times, during the day and in the middle of the night. Workers walking shoulder to shoulder, filling the streets created a sense of power and community.

Entry into the street culture of the city was not easy for migrants. However, despite the insecurities, the hardships - a common trope within which migration stories are written - the city acted as a powerful draw. Individual stories from the past of migration suggest how the desire to explore new places and commune with other young men in the city was attractive to migrants. Personal narratives of male migrants coming to work in the city emphasize specific representations of the rural and urban. For Shriram, who moved to the city when he was around twelve years old, the shift is a moment of self-discovery. Male tales of migration like his tend

I 2. Interview, Shriram.

I3. Adda: meeting place.

I4. Pahalwan: strong man; Shriram, Ek Sarvahara ka Jivan, p. I2.

I 5. A. Niehoff, Factory Workers (Milwaukee, WI, 1959), p. 95. 
to represent men as self-conscious actors, fearlessly confronting problems. Shriram's account touches upon the initial insecurities of city life only to demonstrate how he was able to transcend these difficulties. Once he starts work as a doffer boy in the woollen mills, Shriram invokes a different experience of the city. A sense of adventure, a desire to move on and explore new places takes over. He enjoys the cameraderie (yaraana dosti) with other workers in the factory. But after two years of work in Kanpur, he yearns to travel further and explore new cities. Uncertainty and anxiety now gives way to the theme of mobility, of exploration. Stories are brought in by labour recruiters and others coming from distant places, and these feed into the fantasies of workers like him. Shriram and his friends travel and work in factories in Delhi, Hathras, and then Amritsar. $\mathrm{He}$ comes back to Kanpur, only to move again to Bombay.

In his story, Shriram projects himself as an actor willing to take risks: he can give up a secure job and move to another city; he is in control and can build networks and devise strategies to confront new challenges. His travels from city to city are motivated by a sense of curiosity and a desire to discover new places. Work in new cities allows him to move up to betterpaid jobs - he is pleased to be promoted from a doffer boy to a machine man. Sriram is a male - new to the city but aware of the world, unwilling to be docile and gullible. His return to Kanpur is represented as a shift from a world of deceit and cunning to a world where he cannot be cheated. He feels a new sense of power on returning to Kanpur. His home Kanpur - now becomes a space over which he has control. If there was any sense of powerlessness and insecurity in distant cities, his narrative elides the question. As a male, the theme of insecurity could not be openly acknowledged. We can only read it in his silence.

His story moves by constructing a series of contrasts between the city and country. In contrast to the stereotype picture of simple country folk and wily, deceitful townspeople, he offers an inverse imagery. His relatives in the village are greedy for money. ${ }^{16}$ In the city, in contrast, he finds relatives who care and look after him. Times were good then - one earning member could support a whole family on factory wages. He felt proud of his earnings. Besides the factory he worked in was famous. ${ }^{17}$ The job and wages gave him a new sense of self-esteem. Sriram was writing about the I930s and I940s, when factory jobs gave a different sense of security. His story continuously validates and reaffirms the urban. The urban becomes a metaphor for independence - from the past, from the constraints of the family; it stands for job and earning, male pride, and status.

I6. "They were like vultures waiting to feed on a carcass", (Jaise ki mare janvar ki khal nochne ke liye gidh baithe the [...] vaise vah kar rahe the); Shriram, Ek sarvahara ka Jivan Vritanta, p. 5. 17. "I worked in a factory which was famous all over the country as Lalimli", (Aisee mill mein kam karta tha jo Hindustan mein Lalimli ke nam se kaphi prasidh mill thi [..]]); ibid. pp. 8-9. 
The nature of narratives of the past is defined by the context in which they are written. In a state of joblessness and insecurity today, when factories are closed, the security of the past is overstated. For male workers, factory work defined their masculinity and identity. Work gave them a sense of power, a status in the urban world.

\section{I}

With declining earnings in the city, the rural takes on a renewed significance for worker migrants. For the rural poor who migrated to the city earlier, factory jobs helped to pay back debts and free their land from mortgages. Today, the relationship is reversed and property in the village gives the security which factory jobs gave earlier in a different way. Workers like Ramcharan, who retained a close rural connection, longingly remembered the value of earnings from factory jobs in the past. In the old days, the British zamana (times), he recounted, workers were paid their bonus in silver coins. It was by putting aside these coins that he could buy six and a half acres of land in the village. While the cash value of the coins was not so much, its real value when invested in land seems incomparably greater. To Ramcharan, the incremental value embedded in the silver coins was realized in the phenomenal increase in the value of land. The land he bought for Rs 500 was now, in the I990s, worth Rs $80,000 .^{18}$

In the present context of joblessness and uncertainty, the security provided by factory jobs tends to be overstated, the analogy between land and urban jobs is overstretched. Factory jobs are represented in many worker narratives as an inheritance to be passed down generations. This inheritance ensured a continuity over generations, and a reproduction of skills, which was a basis of worker identity and could become a source of stable earnings for an entire family. The closure of mills, many argue therefore, renders not just the present generation but the future generations unemployed. ${ }^{19}$

Today, male narratives play on images of decay and ageing, drawing comparisons between their decrepit bodies and the worn-out machines in the factory. Work was physically empowering, nonwork created a sense of weariness, a slowing down of body rhythms. In worker narratives of the I990s, there is a distancing from the travails and hardship of work in the past. Factory work is celebrated as enriching and fulfilling. There is a sense of bonding with the machines and the establishments they worked in. Many state proudly how the looms never stopped in their mills. The tight

I8. Interview with Ramcharan who had worked in the Muir Mills since the mid-r94os.

19. Interview, Shriram Sharma, Elgin 2. 
discipline within which they often had to work in the past is recounted by many with a sense of individual achievement and male pride. ${ }^{20}$

While accounts of old workers now amplify memories of work in the past, they tend to repress recollections of strikes, the past history of struggles. Till the early i980s when the factories were still running, workers took pride in narrating stories of the Lal Kanpur days. Today, even those who were witness to the times find it difficult to focus on the experiences of worker militancy. The oral narratives of their past are broken - moving between fleeting recollections of a better time and coming back to the hardships of the present. Some returned to the past only to bring back memories of repression and defeat. In some accounts, time is telescoped, fusing a moment of struggle in the 1950s with stories of police repression and firing on workers in the I920s. ${ }^{21}$ Heroic moments of solidarity are layered in such accounts with the experience of despair and disunity in the present.

The decline in industrial employment in Kanpur is part of a wider crisis affecting all the major industrial centres in India. ${ }^{22}$ This decline is different from earlier forms of de-industrialization when traditional crafts had to compete with factory industry. Today two kinds of shifts are perceptible. One, the modern factory sector is not dominated by industries like textiles, mining, iron and steel that were important earlier; second, there is shift from factory-based production to nonfactory, small-scale industrial production. Within textiles, two kinds of processes are at work. First, the demand for cotton textiles is being increasingly displaced by the growing market for synthetic fibres; second, production has shifted from factories to small power-loom units employing cheap unregulated labour, located away from the old centres. ${ }^{23}$ In Kanpur, the decline can be traced to the I980s, with private industrialists shifting from cotton textiles to other more profitable ventures. The large, state-owned spinning and

20. Interviews, Pramod Awasthi and Muhammad Said, Elgin Mills. Ramcharan of the Muir Mills, for instance, talked proudly of the times when the workers were not allowed to go to the lavatory during work.

21. On this see C. Joshi, "Hope and Despair: Textile Workers in Kanpur in 1937-38 and the I 990 ", in J.P. Parry, J. Breman and K. Kapadia (eds), The Worlds of Indian Industrial Labour (New Delhi, 1999), pp. 197-199.

22. See for instance, Jan Breman, "An Informalised Labour System: End of Labour Market Dualism”, Economic and Political Weekly [hereafter EPW], $36: 52$ (December-January 2002), pp. 4804-482 I; Sharit Bhowmik Nitin More, "Ex-Textile Mill Workers in Central Mumbai", in ibid., pp. 4822-4827; M. Vanamala, "Informalisation and Feministion of a Formal Sector Industry: A Case Study", EPW, 36:26 (June-July 200I), pp. 2378-2389; E. Noronha and R.N. Sharma, "Displaced Workers and the Withering of Welfare State", EPW, no.? (June I999), pp. I454-I 460. 23. On the crisis in the textile industry, see C.P. Chandrashekhar, "Growth and Technical Change in Indian Cotton-Mill Industry” EPW, I9:4 (1984), pp. PE22-PE39; Omkar Goswami, "Sickness and Growth of India's Textile Industry: Analysis and Policy Options", EPW, 25:44, pp. 2429-2439, and 45 (1990), pp. 2496-2506; Tirthankar Roy, "Economic Reforms and Textile Industry in India”, $E P W, 33: 32$ (1998), pp. 2173-2182. 
weaving factories accumulated huge losses in the face of a shrinking market. By the I990s, pressures from the proliberalization lobby mounted and the state increasingly retreated from its welfarist commitments. Committees dominated by experts in favour of a liberal-market regime declared large textile units sick and beyond redemption. Apart from the woollen mills, all state-run units in Kanpur - those run by British India Corporation and others by the National Textile Corporation - stopped production in the early I990s. Three units under the British India Corporation continued to keep workers on the rolls for almost ten years till 200I, and two under the National Textile Corporation are still not formally closed. Only a small proportion of the permanent employees opted for voluntary retirement schemes. Most workers considered the amount offered as compensation inadequate. Moreover, they preferred to remain employees even in fictional terms to early retirement. ${ }^{24}$

For those on the factory rolls, the daily routine for the past many years was to report at the mill gate at shift times. Men sat around, exchanged news, and then wearily traced their way home. Every two to three months workers would be stirred into some action - a sit-in or a demonstration to demand their wages and then hopes were lost again. But for many, being on the rolls and the fiction of work and was important. To take VRS and retire would mean the stamp of unemployment.

How do workers negotiate their lives in a shrinking job market? Working out strategies of survival involves finding ways that give some economic protection and preserve a sense of self and dignity. What are the kinds of strategies that workers devise in this context?

Workers entering their fifties seem the worst affected. After a decade of waiting for the factories to reopen, they feel a sense of tiredness and inertia. Many who worked as weavers in the mills for over thirty years appear bent with age and the vagaries of time. Not only is it difficult to find work but they feel it would never give the same satisfaction. ${ }^{25}$ Families where the men worked as weavers were able to survive in the past on the earnings of one male member. The signs of their status and dignity in the past are now lost. They are dependent largely on the daily earnings of women and children. Being a berozgar (unemployed) is a situation male workers find hard to come to terms with. Not going to work means a diminished patriarchal presence in the household. At a loss, sitting vacant at home, they lurk in corners, shying away from visitors. Their body language, the look of despondency, the thick glasses after years at weaving sheds often tends to mark them out and makes them recognizable as former mill workers.

Unemployed men hang around bastis and hatas, with no fixed schedule.

24. Joshi, "Hope and Despair", pp. I71-204.

25. Interview, Niamat Rasul, Elgin Mills 2. 
Notions of time change when leisure is unlimited: hours and days are whiled away at home or in the gali (alley) outside. Even in domesticity, women tend to have a different regime of time. There are meal times and fixed times when water must be fetched, or vegetables and household provisions bought. Many women are openly critical of men idle, unwashed, sleeping till midday. ${ }^{26}$ Some quite freely make jibes at the men sitting around gambling and gossiping in the hata compound. Loss of work for men implies more than an economic loss. It means also a destabilization of authority within the household and loss of respect in the neigbourhood. Men not usefully occupied become objects of female laughter. ${ }^{27}$

Those who always worked as badlis, or substitute workers and contract workers in the factories, never had the security that permanent workers in the higher-income categories had. Yet there was a difference. Periods of uncertainty were followed by long spells of work. Besides, even as substitutes and contract labourers, they had a distinct identity that marked them off from ordinary casual labourers. Today, these distinctions are no longer valid. Even those with technical skills are levelled down to the ranks of ordinary coolies. Mahboob, for instance, was not a regular employee with any one factory. ${ }^{28} \mathrm{He}$ repaired boilers and worked on a contract basis. With scarcely any factories running, there is no work for boiler repairmen today. Mahboob now works as a palledar (porter), unloading goods from trucks coming to the leather market. He admits that as a boiler repairman he was respected in the factory. He interacted with engineers and important people. Now his earnings are reduced by half and his status has diminished. As a palledar he is anonymous - he is like any other porter in the leather market. Yet Mahboob was unwilling to dwell too much on his loss of status. He moved quickly from the question of hurt pride to the economics of his situation. He distinguished his position from a small vendor on the street - a thelawala. Unlike a thelawala who had no clients to sell to, Mahboob claimed he had work four days a week.

Others who were always a part of the casual labour force have an attitude of resignation. Their routine is fixed. They go to the coolie market in Moolganj every morning, and wait to be hired. If there is no work till noon they return home. Sometimes the ritual wait goes on for days together, with no work. This is the pattern for casual labourers like Durga Prasad, working in the city for thirty years. Sometimes four to five days go past without any work for him. ${ }^{29}$ When there is work he earns Rs 40 at the end of the day.

26. Sameena, in her fifties living with her unemployed son, recounted how he never woke up till I I to I 2. "Is he human", she asked, "sleeping half the day?", (Kya voh insaan hai. Adha din sota hai); Interview Sameena, Fazalganj, Kanpur.

27. Interviews with Shyama and Krishna, Mathiya Vala Hatha, Kanpur.

28. Interview, Mahboob, Gwaltoli, Kanpur.

29. Interview, Durga Prasad, Cooperganj, Kanpur. 
The lives of petty traders in bazaars in working-class neighbourhoods have always been intertwined with those of factory workers in the city. Many of them continue with their old trades but their conditions of work are not the same. Vegetable vendors roam around looking for the stray buyer for their dissipated, unattractive-looking products. With their poor returns they can barely buy any stocks. Some selling eatables - like cooked chickpeas and puris ${ }^{30}$ - manage to put together a cartfull a few days a week. Even the small shopkeeper selling footwear - shoes and slippers of the cheapest kind - feels the difference. Describing their present plight, and how the factories touched their lives earlier, Abdul Parvez, a smalltime shoe trader, made a short speech. Using dramatic gestures and bodily metaphors, Abdul elocuted: "The Elgin Mills were my hands, the Power House my stomach, the Muir Mills my eyes, I could see them and feel full and contented." And this he repeated twice over for effect. ${ }^{3}{ }^{3}$ For small traders like him, located in the earlier hub of working-class activity Gwaltoli - the factories sustained different occupations in the city. ${ }^{32}$ Now everything seemed lost.

Workers' experiences of the present phase of "de-industrialization" are also mediated by gender equations within the family and their caste background. In a labour market where jobs for men are declining, women's earnings are becoming increasingly important as a survival strategy. Yet women's work is a threat to entrenched patriarchal structures and there is continued resistance to it. But strategies of negotiation vary in different types of worker households.

In upper-caste labouring households, waged work by women has always been seen as a violation of family honour. In the present context of rapidly declining family income, they struggle to survive, but continue to seclude the women, resisting their entry into public spaces, seeking desperately to preserve existing gender equations in the household. But the partially employed/unemployed male breadwinner has a diminishing patriarchal presence in the household. With the decline of the male breadwinner, women's work has acquired increasing significance within the household economy. ${ }^{33}$ In many lower-caste working-class households the prejudices against women's work were not so deep. ${ }^{34}$ Yet factory employment for many generations of men, and an improved economic

30. Puri: a kind of bread fried in oil; interview, Hasan Ahmad, Maqbara, Kanpur.

31. Interview Abdul Parvez, Gwaltoli, Kanpur.

32. Gwaltoli was an area where some of the important mills were located and a centre from which important strikes began.

33. For an elaboration of this argument, see C. Joshi, "Notes on the Breadwinner Debate: Gender and Household Strategies in Working Class Families", Studies in History, I 8 (2002), forthcoming. 34. These include castes like Koris and Chamars. Koris were traditionally engaged in weaving. Many women from a Kori background were engaged in occupations like bidi-making and sewing. Chamars were traditional leatherworkers. 
position, had led to a gradual withdrawal of women from waged work, seclusion of women being seen as necessary for claims to higher status. But in a situation of declining male income, women in many such households are now engaged in waged activity at home. Ram Pyari, who makes a living through making bidis, emphasized that in the past when men in her marital household had factory jobs women did not work. ${ }^{35}$ Some who went out to work tried to keep their work a secret from neighbours. ${ }^{36}$

In families where women are now the regular earning members and men are intermittently employed, power relationships at home are often fraught. Men in such families feel a double loss: a loss of their jobs and loss of male authority at home. Yet men struggle to retain their sense of self. Large numbers of labouring men have continued to define their masculinity through drink and their association with male addas. ${ }^{37}$ Family-budget surveys suggest that the expenditure on drink among lower-caste households has been higher than among other castes..$^{38}$ Officials conducting such surveys doubt the reliability of such estimates because lower castes tend to exaggerate their expenditure on drink. Sweepers working in the city, for instance, saw a higher expenditure on drink as a sign of their status. Consumption of alcohol in a context of declining male earnings involved contests over domestic resources and conflicts between female notions of thrift and male prodigality. Many women asserted that the men had to provide for their own drink expenses. ${ }^{39}$ It was common in many households for men to spend the day's earnings on drink, while women provided for the children. Improvidence in the face of adversity was to them an assertion of male pride. ${ }^{\circ}$ Masculine self-assertion also took the form of increased aggression at home. Feelings of emasculation and lost pride are temporarily displaced

35. "My father-in-law worked in a mill so my mother-in law did not work"; interview, Ram Pyari, Chuna Bhatiya, Kanpur.

36. Interview with Asha who worked in a small hardware unit, Afim ki Kothi, Kanpur.

37. A study in the 1960 s showed that liquor consumption was more common in industrial towns like Kanpur. About 70 per cent of the workers in Kanpur were believed to be "occasional drinkers" and 30 to 50 per cent "regular drinkers", who spent on an average around 20 to 25 per cent of their wages on liquor, the amount going up to 50 per cent in the case of single men; Report of the Study Team on Probibition, vol. 2, (New Delhi, 1964), p. 227.

38. According a survey in the I930s, the expenditure on drink among the "untouchable" sweepers was higher than among other castes. The investigators noted: "When we first began our survey we found that most of the sweepers prided themselves on the amount that they spent on intoxicants, this amount being regarded as a sort of index of social status." Report of the Harijan Survey Committee 1933-34 (Kanpur, 1934), p. 30.

39. Interview, Shyama, Lachmipurwa; also Sunita, Tijiya and Rajkumari, Bisati ka hata. This last settlement was inhabited largely by families from the "untouchable" Kureel caste. Kureel men from this locality worked in leather establishments earlier and are now unemployed.

40. Women from many lower-caste households felt it was pointless asking men for money for the household. Sunita quipped: "If we complain that it is difficult to manage, the men tell us to go away with another man”. Interview, Sunita, Bisati ka hata. 
through a demonstration of physical power over women. Women in many lower-caste households were almost resigned to the idea of drunken men beating them up at night. The brute reality of everyday life ultimately structured relationships of power in the household. This is not to draw any necessary connection between feelings of emasculation and violence against women. However, I suggest that the domestic setting becomes a more embattled domain when spaces for affirmation of male selfhood which existed earlier are displaced. Established patterns of male aggression are intensified in a situation where the very identity of the male is under question.

In what way were the issues of identity linked up with the politics of the times? In understanding the recent upsurge in communal strife between religious communities in old industrial centres, some social analysts have drawn a link between this form of violence and the marginalization of the industrial workforce and loss of earlier collectivities important to the working-class culture of the city. ${ }^{4 \mathrm{I}} \mathrm{I}$ emphasize here that for large sections of the marginalized labouring poor an identification with militant Hindu and Islamic movements and a culture of violence becomes a way of recovering their emasculated selves. ${ }^{2}$ The communal carnage in Ahmedabad beginning in February 2002 which continued for over four months, ${ }^{43}$ the violence in Bombay and Kanpur in December 1992 after the demolition of the Babri Mosque in Ayodhya,44 - all occurred in the context of a decline of old industries and the organized labour movement. In Bombay (now Mumbai) right-wing, fascistic organizations, like the Shiv Sena, acquired a wider mass base in the mid-r980s - a period which marked the collapse of the organized labour movement in the city. ${ }^{45} \mathrm{In}$ Kanpur, militant Hindu and Islamic organizations had a larger public presence in a period of collapse of the labour movement in the I990s.

However, some nagging questions remain. Is there not a danger of a

4I. See Jan Breman, "Communal Upheaval as a Resurgence of Social Darwinism", EPW, 37: 16 (April 2002), pp. I $485-1487$.

42. Breman links the intensity of communal violence in working-class neighbourhoods in Ahmedabad with the shrinkage in the dialogic space for communion between communities; ibid. 43. Up to April the number of deaths according to official estimates were 700 while unofficial estimates recorded more than 2,000 deaths.

44. For a background to the Babri Masjid issue, see S. Gopal (ed.), Anatomy of a Confrontation: the Babri Masjid-Ramjanmabhumi Issue (New Delhi, I99I).

45. The decline of the labour movement in Bombay was preceded by an eighteen-month-long textile strike which resulted in virtually no concessions to labour. A detailed, area-by-area account of the Bombay riots is available in the Complete Report of the Srikrishna Commission on Riots in Bombay, www.altindia.net. 
certain form of reductive logic in this argument? Are we to suggest that deindustrialization and unemployment create a situation which inevitably leads to communal violence? How do we conceptualize the connection between politics and the economic context in a way that resists reductive reading?

I argue here that this contextualist explanation of aggressive communal politics can be developed in nonreductive ways. It is not as if there is a large mass of unemployed waiting to be mobilized as mercenaries during communal violence. The point being emphasized is the absence or erasure of an alternative political culture welding wider solidarities cutting across vertical cleavages between communities. For large sections of the marginalized labouring poor, identification with fundamentalist militant Hindu and Islamic movements becomes a way of recovering their emasculated selves. Organizations like the Rashtriya Swayam Sevak Sangh, a militant Hindu outfit with close links with the ruling Bhartiya Janata Party, exhort Hindus to shed their docile, effeminate image and take up cudgels against Muslims. ${ }^{46}$ In the violent events of December I 992 in Kanpur, the working classes - Hindu and Muslim - formed an important part of the rioting mobs. Lower-caste Hindus like Pasis and Khatiks were among those prominently involved in acts of violence against Muslims. ${ }^{47}$ The mobilization of lower castes around communal movements is not entirely new. In the I920s and I930s Khatiks and other lower castes came together with upper-caste Hindus in revivalist activities, acquiring a new sense of status and identity through ties which cut across class lines..$^{8}$ The lines between the pure and impure momentarily blurred as different groups within the Hindu caste hierarchy united against Muslims. After the gruesome killings of both Hindus and Muslims during communal riots in March 193 1,49 Kanpur remained relatively free of such violence even when other regions were riven with strife. ${ }^{\circ}$

46. On the politics of the RSS, see Tapan Basu, Pradip Datta, Sumit Sarkar, Tanika Sarkar, Sambuddha Sen, Khaki Shorts and Saffron Flags: A Critique of the Hindu Right (New Delhi, I993).

47. Pasi: a caste traditionally engaged in pastoral and agricultural activity; Khatiks: traditionally engaged in tending pigs and in Kanpur they were important in brush and bristle-making work. On the social composition of the rioters in 1992, see Paul Brass, Theft of an Idol: Text and Context in the Representation of Collective Violence (Calcutta, 1997). On the identity and politics of Khatiks, see also Maren Bellwinkel-Schempp, "The Khatiks of Kanpur and the Bristle Trade: Towards an Anthropology of Man and Beast”, Sociological Bulletin, 47 (1998), pp. 185-206.

48. On the mobilization of low and intermediate castes around movements asserting a militant Hindu identity, see also Nandini Gooptu, The Politics of the Urban Poor in Early TwentiethCentury India (Cambridge, 2002), ch. 6.

49. In the riots in I93 I more than 400 people were killed and over I,200 injured. A prominent nationalist trade-union leader in the city, Ganesh Shanker Vidyarthi, was brutally murdered. See N.G. Barrier (ed.), Roots of Communal Politics (New Delhi, 1976). 
What is new today is not the fact of communal mobilization but the absence of alternative notions of community and identity. What is frightening about the present is not just the organized political manifestation of communal identity and communal violence but a deeper communalization of popular perceptions, the creation of mental structures that sustains the politics of violence. The shrinking of social and physical spaces which allowed for class solidarities both shape and reflect these changes. The increasing ghettoization of communities, the reorganization of social space in the city, the dispersal and informalization of work - all tend to erase memories of conviviality between communities and harden the lines of cleavage. These changes encode deeper changes in the private transcripts. Impassioned hatred against the other community builds up a palpable sense of threat in ways that were not so apparent at a day-to-day level earlier.

A reticence to talk about issues of communal conflict which characterized the public discourse of workers twenty years back has given way now to an eagerness to express feelings of bitterness and resentment against the "other" community. A separation is still made between spaces where such utterances are legitimate and where they are not. The factory and the millgate were sanitized spaces where the rhetoric of unity - "we are all one", "we live and work together" - are still repeated. Outside, in the security of the neighbourhood, emotions of anger are displayed more openly. Years after the violence following the demolition of Babri Masjid, a Muslim worker recounted in graphic detail the terror and fear of those days. Once he moved away from the mill-gate to his own neighbourhood his vitriolic speech was unstoppable: From time to time, his narrative was broken and recharged with a repetition of slogans which were shouted against Muslims those days: "Katuon ke do sthan, Pakistan ya kabristan"; (There are only two places for katuon or the circumscribed - Pakistan or the graveyard). Even the factory, he recalled, was heavy with tension with Muslims having to suffer taunts and shouts.

In times fraught with tension, stereotypes about the "other" take on new meanings. In lower-caste Hindu neighbourhoods of Kanpur, the image of the wily Muslim doing them out of work is often carried to bizarre lengths. Strangely, in a scenario when processes of "de-industrialization" have had a levelling impact on different categories of the informalized labouring poor, stories are repeated about the hidden wealth of Muslims. Workers making leather uppers for sandals in the Lachmipurwa area in Kanpur

50. Although tension in the city was palpable, there was no generalized violence in the days preceding Partition. On the sense of tension in the city in the r940s, see Soumya Gupta, "The 'Vartman' and Pakistan: The Daily Reality of Partition”, in Ravikant and Tarun K. Saint (eds), Translating Partition (New Delhi, 200I). It was in the I980s that violence on the scale of I93I was repeated; this time it was a pogrom against the Sikhs following the assassination of Indira Gandhi in November 1984 . 
attribute the decline in their earnings to the entry of Muslims into the leather trade. Muslims are represented as "making" the riots: "Hindus have no money, Muslims have the money, they create the riots", are statements commonly heard. ${ }^{\text {I I }}$ In the Chamanganj area, where the relative proportion of Muslims has increased in the last few decades, such feelings were widely shared in non-Muslim working-class households. To many it seemed that Chamanganj was being transformed into a Muslim fortress, a garh. The increase in the number of Muslims was seen as an evidence of Muslim wealth - wealth which was not visible was obviously coming from foreign lands: "Muslims get their money from Arabland", was an assertion which, to them, needed no corroboration - it was self-evident. . $^{2}$

Such representations of the other are not completely novel. They draw on pre-existing stereotypes. But they now seem to have a greater continuity in time, the anger that is expressed in private threatens every moment to spill over into the public. Acts of violence and aggressive postures against the other community are seen as legitimate assertions of male selfhood. In Gujarat in recent months, workers are among those providing muscle power for horrific acts of brutality. Despite an inherent fragility, such alliances between workers and others acquire a threatening resilience in a macabre present where other visions seem to fade and blur.

Processes of de-industrialization in the present context thus have deep cultural implications. The erosion of spaces around which the culture of work and leisure was built has created a crisis of male identities. The invisibilization of men in the workforce touches the inner space of the domestic - threatening male authority in the household, dislocating gender equations. Within this scenario, movements that mobilize around a politics of hatred and communal violence are gaining ground, tearing apart traditions of working-class solidarity and collectivity built up in the past.

51. "Hindu ke pas paise nabi hai, Musalmano ke pas paisa hai vo larvate hain". Interview with leatherworkers in a small workshop in Lachmipurwa. Such statements were also made by many in areas like Chamanganj with a large Muslim population. Women talked of Muslims displacing Hindus in leatherwork, of Muslims buying off houses in this area because they had more money. One of them added: "Muslims are making Chamanganj their fortress. They get their money from Arab”. Interviews with women workers in Chamanganj.

52. Interviews with women in Chamanganj. 